\title{
Midcentury Modern: The Emergence of Stakeholders in Democratic Practice
}

\author{
KAVI JOSEPH ABRAHAM Durham University, United Kingdom
}

\begin{abstract}
Cince the 1960s, "the stakeholder," or affected party, has emerged as a novel democratic subject whose participation in varied institutional sites-from universities to government agencies, corporate boardrooms to international organizations - is seen as necessary for the management of complex problems. However, few specifically attend to the stakeholder as a distinct political subject and consider its implications for democratic practice. This paper presents a genealogy of the stakeholder, documenting its appearance in corporate managerialism and US public administration and showing how racial mobilization, rapid technological progress, and the political rationality of systems thinking provided the conditions of possibility for its emergence. Though orienting democracy around stakeholders permits opportunities for participation in political life, I argue that this subject is predicated on a circumscribed form of participatory politics that erodes habits of discovering a common good, erases distinctions between individuals and corporate bodies, and amplifies the problem of expertise.
\end{abstract}

\section{INTRODUCTION}

D emocracy is a problem. Amid populist mobilizations, transnational racism, deep economic inequality, and a mistrust of institutions at home and abroad, political theorists sense a crisis of democracy (Ercan and Gagnon 2014; Merkel 2014; Merkel and Gagnon 2016; Vormann and Lammert 2019; Westbrook 2021; cf. McCaffrie and Akram 2014; Urbinati 2019, 18). Such concerns are not unfounded: recent surveys suggest that popular dissatisfaction with democracy is particularly acute in the United States and generally rising across the globe (Foa et al. 2020, 9, 19-20). Defenders of democracy often call for a renewal of participation, but such proposals for democratic engagement and participation miss a curious puzzle: the last few decades have seen increased opportunities for public participation in diverse domestic and international institutions (Rosenbluth and Shapiro 2018,3). Specifically, through the language of stakeholder inclusion, participatory appeals issue from corporate boardrooms (Esty and Ciechanover 2021), city councils (Legacy 2010), federal agencies (Mueller 2002), and international organizations (Bäckstrand 2006). Across these varied sites, individuals and groups are called upon to make their voices heard not as citizens (or even lobbyists or special interests) but as "stakeholders." By bringing affected parties or stakeholders to the table, public and private organizations are said to not only develop and implement effective solutions to complex problems but also empower people to participate more fully in political life. And yet such calls for participation have not

Kavi Joseph Abraham (D), Assistant Professor of International Relations, School of Government and International Affairs, Durham University, United Kingdom, kavi.j.abraham@durham.ac.uk.

Received: December 07, 2020; revised: June 08, 2021; accepted: August 23, 2021. First published online: September 29, 2021. correlated with increased satisfaction with or trust in political institutions. How is it that despite opportunities for "stakeholder" participation, democracy remains precarious? How have participatory mechanisms failed to energize democratic attachments?

I wager that the very concept of the stakeholder is significant in making sense of this curiosity, such that any diagnosis of democracy's ills requires a deeper historical understanding of how we became stakeholders. The transition from citizens to stakeholders is a significant one, yet there has been scant attention to it (cf. Bevir 2006; Eagleton-Pierce 2016; Macdonald 2008). In this paper, I compose a critical genealogy of the stakeholder as a novel form of political subjectivity that organizes contemporary democratic practice. I document its appearance in corporate managerialism and US public administration, showing how racial mobilization, rapid technological progress, and the rationality of open systems thinking provided the conditions of possibility for its emergence. I find that the stakeholder has emerged as a subject of democratic governance whose participation is seen as necessary to the management of complex problems. Though oriented to participation, deliberation, and collaboration, the stakeholder, I argue, is predicated on a circumscribed form of participatory politics that erodes habits of discovering a common good, erases distinctions between individuals and corporate bodies, and amplifies the problem of expertise.

I make this argument in four parts. First, I outline the methodological advantages of pursuing a genealogy of the stakeholder and sketch the political rationality of systems thinking. Second, I turn to plotting the emergence of the stakeholder in mid-twentieth-century business managerial discourse. By examining managerial texts, I outline a set of material problems and scientific discourses that make the stakeholder, or affected party, a new object of managerialism. Third, I show how the figure of the stakeholder appears in US government agencies to manage the problem of complexity. It is the convergence of several problematic 
entanglements-including Cold War competition, urbanization, advanced social welfare policies, rapid technological growth, and civil rights mobilizationthat pose a problem of complexity for the state. Through the logic of systems thinking, the stakeholder is articulated as a primary subject of democratic practice, one whose identification and participation could help manage complexity. Fourth, I discuss the implications of this subject for democratic practice and governance. Whereas the orientation to stakeholders resonates with what Kyong-Min Son (2020) calls "instrumental democracy," I find a different relationship holding among participation, elitism, and selfinterested instrumentalism. I conclude with a discussion of how this project contributes to contemporary debates on the role of neoliberalism in the present crisis of democracy.

\section{SYSTEMS THINKING AS POLITICAL RATIONALITY}

How might one go about documenting the production of the stakeholder? This kind of genealogical argument demands a historicity that looks for the discursive production of the stakeholder in institutional settings - not only in academic discourse or the canons of political theory but also in the archives of concrete programs of government. As argued by others (Bevir 2010; McClanahan 2017; Son 2020; Vázquez-Arroyo 2008), my sense is that factors shaping democratic erosion have a deep history that extend to the postwar era. Starting with the subject of the stakeholder, however, genealogically plotting its emergence in managerialism and US government agencies, I locate a different set of problems, techniques, and discourses that transformed democratic practice. To be sure, I am not advancing a linear history, claiming that a patient empiricism of midcentury processes will provide us with the causes of democratic crisis today. Nor is this work meant to displace dominant accounts in the literature that rightly identify how liberal or neoliberal political economy erodes democracy. Genealogy, as Foucault sketches it in multiple places, refuses to "restore an unbroken continuity" between past and present but composes the heterogenous elements, processes, and conditions that "gave birth to those things that continue to exist and have value for us" (Foucault 1984, 81). Rather than read "the past in terms of the present" (Foucault 1977, 31), rather than establish efficient causal mechanisms or linear histories, genealogy is a discontinuous composition of elements that makes the emergence of something possible. As such, I seek to recover those discursive and material elements that made possible a novel political subject that remains important to contemporary democratic practice - the stakeholder.

Analytically, my genealogy is organized around the concept of political rationality - or the discursive forms of political calculation and reasoning from which governance practices, rules, norms, and subjects are specified and intelligibly grounded (Barry, Osborne, and
Rose 1996; Burchell 1993, 269; Dean 1999, 25; Miller and Rose 1990; Rose 1993, 295). As Wendy Brown $(2015,116)$ notes, political rationalities are the condition of possibility for concrete practices and techniques of governing, at once organizing them and serving as their normative basis. They are neither policy paradigms nor abstract philosophical projects that become realized in a deterministic manner but a form of political reasoning drawn from, elaborated through, and grounded in scientific knowledge and through which governance objects, techniques, and subjectivity become possible (Dean 1999, 25). A political rationality not only names a discourse that constructs the objects and techniques of government but also generates novel subjects, new ways of being in the world. While the concept typically organizes Foucauldian accounts of neoliberalism, I use it to conceptualize systems thinking. Specifically, my argument is that the production of the stakeholder as a novel subject of democratic governance was made possible by the political rationality of systems thinking.

\section{Systems Thinking and the Problem of Complexity}

Systems thinking is a transdisciplinary scientific discourse that emerged in the middle of the twentieth century, such that by the 1970 s, diverse academic disciplines were thinking in terms of systems (Heyck 2015, 6-8). From biology to physics, engineering to social sciences, systems thinking constituted a plastic discourse that condensed in different fields, linking approaches such as cybernetics, family systems psychology, contingency theory, system dynamics, and futures studies. Systems thinking was not a coherent paradigm under which scientific disciplines reorganized themselves. Rather, from the 1940s until Ludwig von Bertalanffy's (1968) articulation of "general systems theory," it unfolded as an unstructured discourse in multiple disciplines semiautonomously from one another (Ackoff 1974a, 12-3; von Bertalanffy 1968, 30-1).

A first cut in grasping systems thinking involves the distinction between closed and open systems. Though both closed and open systems thinking seeks to understand phenomena by modeling the holistic interaction of parts, closed systems thinking does so on the assumption that connections among parts are bounded and that they can be reduced to homogenous quantifiable forms. Closed systems tend to be isolated from their environment, operate under predictable conditions, and therefore, are more easily governed by techniques of command and control. Closed system thinking is indicative of the changes that swept the Department of Defense (DoD) under Robert McNamara, Charlie Hitch, and figures from the RAND corporation (Amadae 2003, 62-4), and it informs inquiry into midcentury democratic governance. Son (2020,105), for instance, names "systems science" as contributing to the making of "instrumental democracy," arguing that it renders democracy as a "controlled system" that merely collates individual 
preferences and, therefore, "dispenses with the need for citizens to determine their collective goals through public deliberation." Advancing this position through a reading of David Easton's model of political systems (71-2), Son finds unresolved tensions in Easton's notion of "dynamic stability" - or the principle that posits responsiveness to changing public demands as necessary for stable political systems (80-2). Son argues that centralizing tendencies persist under dynamic stability in that systems science-the kind operative at the DoD (86-8) - is premised on a distrust for the rational capacities of individuals (84), requires decision making to be concentrated at the top (85), and presumes that the character of problems can be reduced to "homogenous quantitative data" (88). Thus, for Son, not only is democratic subjectivity transformed into self-interested instrumentalism such that individuals do not collectively decide on political issues but merely register individual preferences (105); the political system itself likely gravitates toward centralization and hierarchy.

While Son arrives at the significance of systems thinking for understanding transformations to democratic thought, he largely elides another strain that emerged at the same time, "open" systems thinking. ${ }^{1}$ Open systems are embedded within an environment that permits interaction, change, and consequently unpredictability. Exchanges with an environment allow for unforeseen inputs, rendering open systems as deeply complex and adaptive. Thinking in terms of open systems, then, brings to fore patterns of selforganization and decentralized regulation, dynamic or nonlinear processes, emergent effects wherein the whole is more than the sum of its parts, and entangled relationships between organisms and their environment. Though closed systems thinking was important in US public administration, a deeper interest in complexity, adaptation, and spontaneity within systems allowed the minor discourse of open systems thinking to institutionally emerge in the late 1960s. It is open systems thinking that concerns the discursive production of stakeholders.

At the center of open systems thinking is the problem of complexity. As von Bertalanffy $(1968,5)$ makes evident, the shift toward thinking in terms of systems arises due to the difficulties of thinking in Newtonian terms about exceedingly complex phenomena. Systems thinking, then, is a discourse seeking to understand the organization of complexity (Heyck 2015,9), using techniques and forms of explanation that cannot be limited to efficient causal relations - that is, because of $X$, we have Y (Ackoff 1974b, 2). Complexity was not merely an abstract academic problem but a practical one organizing social and political life in the middle of the

\footnotetext{
${ }^{1}$ The distinction between closed and open systems thinking is analytically useful, though admittedly blurred in practice. As I read it, Easton's political systems allow for inputs from an environment but is interpreted by Son as disposed to centralization/hierarchy based on the closed systems principles that form the background of Son's postwar history (86-90). Son (208, fn. 74-5), however, acknowledges other more democratic applications of systems science.
}

twentieth century. The complexity of midcentury living was captured by atomic explosions and the first glimpses of the Earth from space, integrated circuits and internetworking, high rates of urbanization and education reform, racial political activism and decolonization struggles, biological weaponization, and ecological degradation-all of which took place in the wake of global economic depression and industrialized genocide. Together these diverse yet entangled processes created a sense of unwieldy complexity, a sense that social change and technological innovation exceeded human control.

Thus, I argue that (open) systems thinking is a distinct political rationality forming in the middle of the twentieth century, one oriented to complexity and regulative techniques that account for dynamic environments. To be sure, concepts of complexity and systems did shape diverse political positions and are therefore entangled with other political discoursesnamely, neoliberalism. As many have noted (Caldwell 2016; Connolly 2013; Cooper 2011; Walker and Cooper 2011), Friedrich Hayek's ([1964] 1994) later work engages with open systems concepts, arguing that complexity evidences the limits of scientific knowledgeand, by extension, hubristic interventions into the market (65). In fact, Hayek has served as a touchstone for those linking (or delinking) contemporary discourses around resiliency, systems thinking, and neoliberalism (Joseph 2013; Walker and Cooper 2011; Zebrowski 2013; cf. D. Chandler 2014), demonstrating that the genealogies of systems thinking and neoliberalism are entangled. And yet, while these discursive elements meet at different historical junctures, I argue that systems thinking and neoliberalism name different political rationalities with distinct problems, forms of reasoning, ideal techniques, and political subjectivities.

Neoliberalism is notoriously difficult to pin down (Venugopal 2015), often referring to a set of economic principles adopted in the US and the UK in the 1980s: limited government intervention, privatization of primary industries, open trade, and relatively free/deregulated markets (Klein 2014). However, I follow Foucault and his interlocutors who understand neoliberalism as an art of government (see Ferguson 2010). As Brown (2015, 21) argues, neoliberalism not only "names a historically specific economic and political reaction against Keynesianism and democratic socialism" but also refers to "a more general practice of 'economizing' spheres and activities heretofore governed by other tables of value." Neoliberalism, then, is not simply a set of economic principles but a broader political-and, indeed, moral (Brown 2019; Cooper 2017)-project that seeks to support a competitive market. It is both an intensification of a classical liberalism marked by dramatic austerity and a reprogramming of liberalism wherein the central problem of government is distinct: whereas liberalism poses clear limits to governmental practice, specifying that the market must be left alone, neoliberal governance continually marshals the state to enable the flourishing of the market. Neoliberalism does not hold the market as naturally competitive; rather, the problem of neoliberal governance concerns 
the production and maintenance of competition (Foucault 2008, 118-29). Further, neoliberalism cultivates a specific kind of entrepreneurial subject, one who continually invests in and takes responsibility for oneself (Foucault 2008, 241-2). Therefore, the constitutive problems, practices, and forms of subjectivity are distinct from systems thinking. As I detail below, the rationality underlying stakeholder inclusion not only appeared prior to "actually existing" neoliberalism in the 1980s (Brenner and Theodore 2002) but also did not concern problems of competitive markets, normative valuations of individual freedom, or cultivation of enterprising subjects. Instead, the stakeholder was a midcentury production, posed as an object and subject of democratic governance necessary to manage complexity and permit long-term survival of institutions.

\section{SYSTEMS THINKING, MANAGERIALISM, AND THE MAKING OF STAKEHOLDERS}

The contemporary meaning of stakeholders, as an affected party or one who has a stake in some problem, transaction, or process, originated in midcentury business managerialism and was made possible by concrete problems and scientific knowledges. Specifically, it was complexity and the question of long-term survivability of the firm that made the identification and participation of stakeholders a matter of sound managerial practice (though certainly not one always taken up by corporations). While the idea of being accountable to not only shareholders but also stakeholders aligned with an existing discourse on corporate public responsibility, I maintain that the figure of the stakeholder was a specific kind of object discursively produced and disseminated as the firm became defined through the logic of open systems thinking. That is, once the firm was no longer conceived as an independent entity but rendered in open systems terms, as embedded within an environment and connected to a variety of parties that may be affected by and therefore could affect corporate activity, this affected party or stakeholder emerged as an object of managerial practice. Briefly, open systems thinking predicated the long-term survival of the firm in complex and dynamic environments on the identification and management of its diverse stakeholders. As a result, the stakeholder named something different from "the public" or "society." Indeed, the stakeholder was defined in relation to a problem or product, whose identification and participation in producing outcomes were required not out of ethical but managerial concerns.

To be sure, shifts in managerial thinking and practice did not come from ideas about systems alone but emerged in the context of heterogeneous material and discursive processes out of which the problem of complexity was defined and elaborated for the corporation. Postwar United States was marked by the growing size and influence of corporations, which made them targets of political action. Labor unions, environmental movements, consumer activism, and civil rights groups mobilized against US corporations.
Simultaneously, dynamics internal to industry like corporate mergers, multinational operation, and tensions between owners and management upset institutional stability. The conjunction of these historical processes constituted the problematic material out of which systems thinking defined the problem of complexity for corporate management and posed new objects and practices for how to properly manage the firm. As corporations became sizable institutions, as their products diversified through mergers and acquisitions, multiple questions arose concerning how to manage diverse activities and allow these institutions to survive over the long term (March and Simon 1958, 4). As corporations grew and shareholders diversified, the distinction between ownership and management grew stark, with owners seeking immediate returns on investment and managers seeking to maintain the organization's viability in the future (see Chandler 1977). The split between owners and management (or, crudely, short-term profitability versus long-term survivability) further manifested as fissures in preferred managerial techniques-rational efficiency, on the one hand, and long-term desires for flexibility, on the other (Smith 2008, 36). Whereas efficiency and rigidity benefitted short-term profits, to survive in the long-term, firms had to adopt more flexible and open understandings of corporate activity (50). Systems thinking, liaising with these material shifts, provided new models of managing the corporation (cf. Boltanski and Chiapello 2007) that pushed against older ones focused on hierarchical control of capital for the generation of short-term profits-that is, scientific management (Taylor 2012, 9-11). It instead emphasized adaptive practices of long-term survival under conditions of complexity (Smith 2008, 48).

In what ways could the firm simultaneously adapt to and manage this dynamic environment? Systems thinking premised organizational survival on accounting for the multiple affected parties or stakeholders that influenced its activities (Freeman 1984, 32). The interests of workers and customers, contractors and competitors, government agencies and environmental lobbyists - or all who had a stake in the actions of the company-had to be systematically identified and regulated for a firm to succeed. Many systems managerial theorists (Churchman 1968; Emery and Trist 1965) articulated the stakeholder as a primary and novel site of corporate action, but Russell Ackoff's (1970; 1974a; 1974b) work is illustrative. For Ackoff $(1970,2)$, it was the problem of complexity that required new management systems such that the very concept of corporate planning was rendered in terms of a "system of decisions." Ackoff argued against analyticism, the breaking down of corporate planning into independent subsets (2). Instead, successful planning saw decisions in each stage as interrelated - that is, each stage was constitutive of an adaptive planning system that responded to its environment. To be sure, social responsibility was important, as Ackoff's $(1974 a, 56)$ version of systems thinking necessitated that component parts take "responsibility for the welfare of the whole." As such, his systems managerial 
theories connected with discussions around business ethics and social responsibility, but his defense of posing the firm on such grounds depended upon rethinking the purpose of profit maximization. According to Ackoff (1974b, 15-6), "the objective of the corporation should be stated in terms of what profit can be used for," and its use depended on the interactions of corporate activities with different internal and external "stakeholders." The modern firm, Ackoff argues, interacts with many "participants"-employees, customers, suppliers, investors, debtors, the public-and "these exchanges involve both individuals who are part of the corporation and other individuals and organizations that are part of its environment. These participants in corporate affairs have come to be known as stakeholders" (16). Thus, long-term survival and interests of the corporation would be served by benefitting their environment because in an age of systems, such flexible and inclusive adaptations to environmental elements were necessary.

Managerial techniques and practices oriented toward "stakeholders" was not an academic exercise but represented a minority discourse across corporate board rooms, think tanks, and academia. In fact, according to R. Edward Freeman's (1984, 32-3) oftcited history of the term, the earliest statements naming "stakeholders" as affected parties upon which a corporation depends came in the early 1960s at the Stanford Research Institute (SRI). Stakeholder theory, Freeman et al. $(2010,46)$ tell us, became "gospel" at SRI, developed in internal meetings of the Theory and Practice of Planning committee and then circulated in internal memos, academic articles, and external reports. SRI's own historical ledger credits Robert Stewart with coining the term. Stewart, who worked at Lockheed alongside famed strategic management theorist, Igor Ansoff, developed a model of corporate planning ("SRI System of Plans") in the Theory and Practice of Planning committee in which stakeholder analysis figured as central. This system of corporate planning was widely disseminated to executives across the globe between 1965 and 1971.

J. Douglas McConnell (1971), a market economist at SRI, provides a glimpse of SRI's institutional thinking on corporate planning that evidences how complexity and the logic of systems thinking made the stakeholder a novel target of managerial practice. "In today's large complex organization," McConnell argued, "the planning process has to be formalized" (2). The first step in the methodology of planningwhat SRI called "organized entrepreneurship" - was to understand the objectives of a firm, the "complex" unfolding of which must "take into account the expectations of the several stakeholder groups, the corporate skills and resources, and environmental change" (3). McConnell defined "stakeholder analysis" as the appropriate tool for developing the "hierarchy of objectives" for corporations, a tool that involved analyzing how the different constituencies may affect a firm, including "stockholders, employees, management, functional groups or divisions, customers, distributors, suppliers, financial institutions, and the communities in which it operates" (3). Strategic planning, then, had to assess internal skills and competencies as well as environmental factors, or the "physical, economic, social, political and technical" context in which the firm was situated (5).

The importance of scientific knowledge in articulating the stakeholder is not to dismiss the very real conditions and social pressures that pushed for corporate responsibility, but the production of the stakeholder and other seemingly "democratic" impulses in the corporate world cannot be reduced to a placating response to social mobilization. Rather, it represents an epistemological rethinking of the corporation, its purposes, and its prospects for survival. Whereas some notion of corporate accountability to "the public" has currents going back to the first decades of the twentieth century, it is the rationality of systems thinking that defines the "stakeholder" as a managerial object distinct from the public or society in general. Whereas public accountability creates a direct and simple relationship between two things (the firm and a bounded community), stakeholder management differentiates the external environment of the corporation into multiple groups that are positioned in differential relationships. Redefining the public into groups of affected parties alongside others such as employees, shareholders, and customers both deterritorializes corporate activity and establishes inequality among affected groups. In other words, corporations are not responsible to a clearly demarked citizenry but only to those parties that emerge in relation to its actions and behaviors, and the importance of these groups depend on the extent to which they can disrupt or otherwise affect the firm. The shift from "the public" or "citizens" to "stakeholders" marks an important transformation of democratic participation once this figure enters the state.

\section{TRANSFORMATIONS OF DEMOCRATIC SUBJECTIVITY}

As systems thinking emerged in midcentury corporate managerialism, this concern with complexity was simultaneously translated within areas of US public administration. Due to Cold War competition, the federal government became involved in educational and technological policy, and open systems thinking emerged as the political rationality by which "the stakeholder" was posed alongside the citizen as the subject of democratic governance. Though democratic theory and practice have long been suspicious of the intelligent capacities of the public (Rancière 2014), the midcentury problem of complexity renewed questions about the "omnicompetent" citizen. In the context of rapid change and deep complexity, government officials, pundits, scholars, and others asked whether the average citizen in a democracy could intelligently manage problems ranging from the nuclear arms race to urban development (see Amadae 2003; Heyck 2015). Limiting democratic engagement to only those who were affected by specific policies allowed for a 
circumscribed participatory mechanism to be advanced - one based on stakeholder expertise - while effectively sidelining accountability to the broader public and eroding the basis for collective decision making.

\section{Educational Experiments: Race, Social Welfare, and Stakeholders}

The stakeholder emerges in the 1960s and 1970s in relatively novel fields of federal government intervention: education and technology. Though seemingly disparate, these policy areas were interrelated given the context of Cold War competition. Historically, primary and secondary education in the US was a local matter to be determined by municipalities and states, but after the launch of Sputnik, education became linked to federal governance of technology and national security. The National Defense Education Act (NDEA), passed in 1958, authorized millions for science and mathematics education, language and area studies, student loan provisions, grants to secondary institutions, graduate fellowships, and vocational training in technical industries (Urban 2010, 2-4). Legislative debate on the NDEA, as Barbara Clowse (1981) documents, was organized around whether the US could compete with the Soviets. At the same time, education became a primary site in the struggle for racial equality. The National Association for the Advancement of Colored People's (NAACP) work in challenging white supremacy and racial segregation resulted in the 1954 landmark decision, Brown v. Board of Education, which coupled with the NDEA opened the way for federal intervention in schooling. Thus, national security, civil rights activism, and social welfare were linked by the 1960s.

Federal interventions in education did not take the model of universal welfare but targeted programs directed at reducing inequality among socioeconomic groups. The Elementary and Secondary Education Act (ESEA) of 1965 established a strong federal role for basic education, targeting disadvantaged lower income and minority groups through programs like Head Start and Follow Through. The ESEA, like other Great Society initiatives, was predicated on closing racial and socioeconomic disparities through differential interventions. Because their success required a reduction in social stratification, a class of expert evaluators was needed to assess the effectiveness of social policy, one that could help design, monitor, evaluate, and improve these programs. Thus, the rise of the welfare state created a need for experts, a situation that helped establish a science of program evaluation (Rossi, Lipsey, and Freeman 2003, 12-4). Such monitoring and evaluation were contracted out to private research firms, such as SRI, which drew upon the logic of systems thinking to make sense of targeted policy interventions.

Indeed, it was through SRI's research papers on educational programs that the articulation of stakeholders, as opposed to citizens or other democratic constituencies, first appears in government documents. Initial introductions are found in reports developed by
SRI's Educational Policy Research Center in its evaluation of urban school programs and minority education initiatives. As early as 1967, stakeholder analysis was proposed as an integral tool for the Department of Health, Education, and Welfare (HEW), with SRI arguing that accounting for stakeholders was the best means to produce policy more responsive to and less likely to incur resistance from different social groups (Thomas 1967, 6). Underlying the need for stakeholder inclusion was systems thinking. In the report for the Office of Education, SRI foregrounds stakeholder analysis in developing educational policy geared toward "the poor minority child who lives in the inner city" (1). Stakeholder analysis supports effective policy implementation by not only assessing how goals are met but also accounting for individual effects that a policy will have on different parties (4). Because "[f]ew, if any, programs for education in the inner city will be singular and discrete" (16), SRI maintains that educational policy should always be situated among broader social goals, and as such the "noneducational" effects of policy must also be considered. In recognition of racial divisions and civil rights activism, SRI outlines the import of governing through stakeholders.

\begin{abstract}
The concept of "stakeholder," borrowed from SRI's work in corporate planning, may be useful in this regard. A stakeholder is any individual or group who has a stake in, that is, will be affected by, the outcome of a particular decision. Every group within the society is a potential stakeholder depending upon the issue. Educational decisions intended to affect the skills, attitudes, or values which students acquire in formal education make stakeholders of nearly everyone for the decisions affect the future of society. (16)
\end{abstract}

The report goes on to specify the temporality of stakeholder practices, noting that as "an organization evolves and the environment changes," the interests and goals of stakeholders will also change (19). Grounded in systems thinking, SRI argues for the importance of engaging stakeholders continually as environmental influences shift the priorities of affected parties and the organization.

The racialization of education policy was explicit in SRI's analysis of urban education, both in defining the contours of specific problems and positioning stakeholder identification as necessary to solve them. A report on improving urban educational facilities begins by noting how the "rapid influx of poor minority groups has compounded" preexisting problems with school infrastructure while creating overcrowded classrooms (Thomas 1969, 1). To study the problem, SRI poses a methodology between an "in-depth technical study and a general systems approach," finding the latter's focus on quantitative inputs insufficient (2). Though not specifically naming an "open" systems approach, the report is premised on understanding school systems as "in a precarious relationship with their environment (parent, civil rights groups, black militants, teachers' unions, and students)" (2). Proposals for expanding educational infrastructure will, therefore, necessarily 
affect diverse constituents such that SRI must parse "negative" stakeholders, only interested in constraining change, and those that seek "positive" control such as "white liberals," "black militants," and "the teachers" (4). Through consultation and dialogue with these groups, SRI outlines how specific proposals such as educational parks and mini-schools meet or fail to meet the expectations of primary stakeholders, using consensus positions to frame their interests. Such interests, to be clear, are not limited to registering individual preferences but take on a deeper recognition of political claims, such as liberal desires for integration and "Black militant" desires for disrupting institutional racism (8). Indeed, SRI advances the somewhat radical proposal of community-controlled schools, though they caution that what is to be taken away from the report is not the policy recommendation, per se, but an understanding of how to recognize and work with the "driving forces" that exist in each policy context (125) - that is, stakeholder analysis is itself the recommendation.

The focus on governing stakeholders to manage complex policy interventions and dynamic environments continues in subsequent SRI documents (e.g., Thomas and Harman 1972). In a two-volume report on Knowledge Production and Utilization (KPU) in education policy, the political rationality of systems thinking as that which governs through the subject of stakeholders is explicit (Markley 1975a). The 1975 report examines a "systems mapping approach" to assess and monitor initiatives for the National Institute of Education (xxi). SRI predicates their work on historical changes in federal research and development in education, noting that the ESEA permitted greater interest in the production of knowledge and its use within school systems (2-3). Critical in this moment, the report argues, was the influence of systems analysis at the DoD, which influenced the conceptualization of education R\&D as "a system with nested subsystems" (3). But contrary to the closed systems principles found at the DoD, the report pushes for open or living systems approaches, emphasizing self-organization, adaptation, co-evolution, and environmental interaction (166-7).

In the second volume of the report, SRI applies their framework to several case studies, where the report's conclusions make the reasoning for stakeholder inclusion legible through the logic of open systems thinking.

One of the systems principles that seems to occur throughout all hierarchically organized systems, whether they are "mechanical" or "living," is the phenomenon of "hierarchical emergence." This is the phenomenon through which a new coherent system property "emerges" when a series of lower order systems or configurations begins to work in close interaction over time, so that the new higher level configuration or system can have stable properties of its own... . As is true in all living systems, however, the survival probability of a mutant organism or species is small unless the mutant has, by virtue of its mutation, a superior advantage in its life-support transactions with the ecological networks surrounding it. This principle, translated relative to KPU, means that NIE as an institution and KPU as a concept must always have "currency" (legitimacy and value) to the principal stakeholders in the KPU community. Only then can KPU guarantee its survival in the "jungle" through which its allocations policy is formed. (Markley 1975b, 48-9)

Thus, the report recommends the "need for strong political support from the community having vested interests in effective KPU in education" (49).

To be sure, while SRI educational policy reports delivered to HEW are central to this story, other documents push against ascribing causal agency to any one actor. Rather, there were multiple places in which the language of stakeholders came to inform US public administration. As early as 1970, Adolph Koenig of the American Educational Research Association delivered a paper on the management of educational research in the United States. Discussing the possibility of a National Institute of Education to coordinate research into educational policy under HEW, Keonig $(1970,14)$ emphasized that "the institute's strength will come from a well-developed policy, planning and priority setting machinery involving representation from the several communities and groups of stakeholders concerned with the health of education." Organizing the planning process will require the institute to "bring modern management technologies to bear on the problems of resource allocation for research, development, and adoption" (15). Indeed, it is the rationality of systems thinking that makes corporate managerial models and techniques desired:

Differentiation of function and mechanisms for planning, coordinating, priority setting and decision-making are key elements in systems to articulate knowledge into practice. Linked systems of differentiated capacities which bring to bear critical masses of resources and deal with real problems are a necessity and will require improved management... Indeed, the concepts underlying techniques such as a management of objectives, contingency management, convergence and Delphi techniques, strategic planning and a host of lables [sic] associated with evaluation and supporting operations research activities will become more familiar. (11-2)

Notably, though Koenig's paper calls for stakeholder inclusion to organize systems of education management, there is no reference or citation to SRI. Thus, the language of stakeholder inclusion was increasingly becoming naturalized in a variety of educational institutional assessments (e.g., Garman and Hunter 1978; Hood and Blackwell 1975; McClure 1977). By the late 1970 s, summative reports on "Multiple Stakeholders and Evaluation" in education policy were reviewing the state of the art of governing through stakeholders (Eichelberger 1978).

In midcentury educational policy, then, the stakeholder began to stand in for the citizen or the public as that to which government programs must identify and respond. However, institutional discourse was primarily concerned with producing the stakeholder as an object of governmental practice. In the next section, I present the process by which the stakeholder was 
explicitly articulated as a novel kind of democratic subject distinct from and superior to the citizen.

\section{Technological Progress against the Omnicompetent Citizen}

As with education policy, Cold War competition shaped discussions on technological innovation. But while technological progress became part of national security, environmental movements, community resistance to nuclear power, and consumer rights groups questioned the unintended and unaccounted effects of rapid technological change. It was from within this problematic context that the stakeholder was posed as the proper subject of democratically governing complex issues. The Office of Technology Assessment (OTA), established in 1972, was tasked with regulating and evaluating the generation and proliferation of new technologies in a way that was socially beneficial, but the complexities of governing technology posed problems for democracy itself. If governing technology was necessarily complex, requiring specialized expertise from different sectors and disciplines, how should different constituencies be involved in developing and implementing regulations? Who should be recognized and included? How could these complex proceedings be made publicly legible? As Edward Kennedy, Chair of the Board of the OTA made clear, the agency was "not only an experiment in technical analysis" and "institutional reform" but also democratic governance (OTA 1975, 60). The OTA was needed for Congress to "cope with complex technical issues" and be a source for "unbiased technical expertise," but Kennedy noted,

[i]t is not just a matter of whether Congress can utilize technical information and advice. The crucial point is whether Congress can do so in the full glare of public scrutiny-and with the full participation of the varied public groups that have a stake in the outcome of the decisions. Thus, the Advisory Committees we have established contain not only the technical experts, and the economists, lawyers, and sociologists - but also the representatives of labor and industry, consumers, environmentalists, and other interested segments of the public. (60)

Seeking the "full participation of the varied public groups that have a stake in the outcome of the decisions" and creating advisory committees made up of "interested segments of the public" specify the stakeholder rather than an individual citizen or the public as the subject of democracy. It is not the citizenry that concerned Kennedy but only those who had skin in the game, who had "a stake in the outcome." Like the changes in educational policy outlined above, what made this shift possible was the political rationality of systems thinking responding to material problems of complexity.

Technology assessment, according to initial OTA proceedings, was needed because technological change was outpacing the ability of individuals to manage unintended effects (US House of Representatives
1967) and the "growing complexity of society" was connecting numerous, seemingly distant social elements in surprising ways (Coates 1971, 226). Thus, concern over rapid social and technological changes required new techniques to anticipate and mitigate potentially negative effects (Arnstein 1977, 572-3). These techniques - indeed, the whole field of technology assessment-was based on systems thinking. As Emilio Daddario defined it in early Congressional statements pushing for the creation of the OTA, technology assessment was "a system to ask the right questions and obtain correct and timely answers" about future consequences (quoted in Hahn and Chalk 1972, CRS-16). Even as Joseph Coates (1976,140), Assistant to the Director of the OTA in the 1970s, asserted that there was "no methodology, no algorithm nor paradigm, which will define or yield a technology assessment," he nevertheless organized the definable elements and useful models of technology assessment through the logic of systems. In 1976, Coates outlined 10 elements of the technique that began with examination of "problems statements" and shifted to various steps, including the specification of "system alternatives" and "macro system alternatives" (140). According to Coates, defining systems was "a key part of a technology assessment, inasmuch as that is the only way to define a useful range of systems alternatives to be studied" (141). Moreover, the suggested models for technology assessment included "system dynamic modelling," developed by the systems theorist, Jay Forrester, environmental models known as Strategic Environmental Assessment Systems (SEAS), and scenario planning.

In reflecting on how to govern technology, the stakeholder appeared as the kind of political subject necessary to deal with complexity while "saving" democratic participation. Walter Hahn (1975), a staffer from the Congressional Research Service, cast it in explicit terms:

The advent of technology assessment raises some unique and as yet unanswerable questions about "participation." Technology assessment is a highly sophisticated process involving expertise in a variety of advanced and complex analytical techniques... . Not only are there complex interactions among these experts, but between them and those who must make the decisions. Some have characterized these interactions as those between the practitioners and those in the power structure and between experts and, relatively speaking, laymen. But there is a third party to the technology assessment process, the affected party... . This "stakeholder" is a primary party favoring an outcome in his specific interests. (77)

The question of democratic participation emerged early in the making of the OTA. It was clear that "expert" knowledge was needed but the prospects of veering into technocracy prompted questions about whom among the public should be able to participate. In fact, according to a review of legislation leading to the creation of the OTA, a Congressional Research Service's report specified just how integral the question 
of public participation in technology assessment was to its making. But, the "public" was not an assembly of equal citizens but differentiated into "affected parties, highly organized groups, diffuse interests, and apathetic members" (Congressional Research Service N.d., CRS-2).

This shift from the public to affected parties or interests (i.e., stakeholders) was shaped by court decisions on the environment, wherein the "affected party" became legally recognized (Green 1968). However, arguments that transformed democratic participation in terms of stakeholders did not appeal to legal precedent but to managerial techniques. In testimony to the House Subcommittee on Science, Research and Development, for instance, Richard Carpenter, Chair of the Engineering Foundation Research Conference on Technology Assessment, set the solution to governing somewhere between "technocracy" and "chaos," or between technocratic leadership and the "full participation" of citizens (quoted in Congressional Research Service N.d., CRS-11). "The question," Carpenter maintained, "is how to take advantage of the knowledge necessary to run a big, complex society without giving up the values of participation. The answer we're looking for is a third way" (CRS-11). Carl Bruch of the Brookings Institution echoed the problematic premise of managing complexity:

As our society increases in technological complexity, the price of an error in the risk/benefit equation is constantly increasing. Because the future destinies of so many people are affected by any decisions that governmental agencies make in terms of technology assessment, I feel that there has to be more input from the public. Such inputs can come not only from the highly organized interests but also from all those affected by any technological decisions so that our society does have a democratic decision-making process at work in such technological evaluations. (CRS-11)

Louis Mayo (1969), involved in the making of the OTA, also pushed strongly for participatory mechanisms in technology assessment (91), but public participation only referred to affected parties. Indeed, for Mayo, a single "public interest" did not usually exist in complex situations.

When such elements of uncertainty exist, sharp differences of opinion inevitably arise since some segments of society benefit and others suffer. Why should we reasonably expect that such matters be determined without resort to some form of adversarial system and the opportunity for affected participants to state their positions? (57)

As Christopher Wright, a professor at Columbia University, summarized in his 1967 testimony,

On the question of public information ... we have now reached the point where we ought to refine the concepts of public information by realizing that there are many different publics, and that it is no derogation of democracy to recognize that as a statistical matter there are few occasions on which many members of the total population will focus on any one issue simultaneously. (Congressional Research Service N.d., CRS-6)

Confronted with a rapidly changing and complex environment, formulations of political participation at the OTA refused the idea that the institution could be used for arriving at a common good or provide a space in which interested and disinterested members of the public can collectively arrive at decisions. Rather, to manage complexity through relevant expertise, democratic participation took the form of stakeholder inclusion.

\section{STAKEHOLDERS AND THE EROSION OF DEMOCRACY}

A constitutive problem for midcentury governance in concrete spaces of public administration was how to manage complexity in a democratic polity, how to maintain a sense of accountability and participation in the presumed absence of an informed and intelligent public. Democratic governance refused the possibility of wider public discussion on and solutions to complex problems, limiting participation to those who had a stake in the specific issue. The political rationality of systems thinking, I argue, underpinned such institutional solutions and articulated the stakeholder as a novel subject.

How, then, does the emergence of stakeholders in democratic practice limit engagement and participation? How do increased opportunities for political participation correlate with democratic detachment? Few political theorists hold systems thinking and managerialism as culpable for democratic detachment, save for notable exceptions. Mark Bevir (2006, 427), for instance, discusses "systems governance," along with its emphasis on stakeholder inclusion, as an elitist project rather than something radically democratic. Bevir, thus, holds social scientific discourses on new institutionalism and communitarianism as culpable (427), arguing that stakeholder inclusion is about elites soliciting buy-in rather than open processes of collective decision making (432-4). Sheldon Wolin (2008, 135), on the other hand, tracks managerial influences in democratic practice to the postwar era, arguing that such influence in government has had a corrupting effect on public institutions as well as the public interest. The figure of the manager, Wolin contends (222), is central to the elitist project of "managed democracy," which dampens political participation and undermines commitments to political equality and the common good.

Treading the same historical ground as Wolin, Son (2020, 68-9) deftly pushes against accounts that render the problem of democracy as a symptom of elitism. For Son, it is less important that participation has been suppressed than the very concept of participation has been redefined in terms of individual instrumentalism. "Postwar democratic theory," Son (176) makes clear, "does not simply narrow the scope of political participation but alters its terms and 
changes the environment in which it takes place." Rather than collective cooperation, inquiry, and decision making, rather than coming together to decide on the common good, democratic participation under systems science becomes "an instrument that individuals use only to pursue their private interests" (176). Thus, the problem of democracy is not a turn to elitism and the suppression of participation (177), per se, but the reframing of participation as a mechanism to realize one's own self-interest.

By focusing on the set of discourses and material practices that articulate the stakeholder as a subject of democratic governance, by engaging with the political rationality underpinning concrete programs of government, my genealogy arrives at conclusions that resonate with but also push against this literature. Despite its participatory and deliberative character, I argue that the figure of the stakeholder erodes democracy in at least three ways. First, though the stakeholder or affected party is a participatory subject, the form of participation fails to cultivate habits of discovering a common good. On my view, for democracy to be meaningful, it cannot be reduced to a thin set of procedures and institutions that represent the public interest but must involve a deeper commitment to the experience of political equality (Brown 2019, 24-5). Such a commitment to political equality is not merely a guiding principle of institutional order but one that must present in the everyday experience of engaging and negotiating with others. Such a pragmatist understanding of democracy, as John Dewey ([1939] 2021, 62-4) argues, figures democratic equality as something that is lived, a continual faith in "human equality" and a "belief in the ability of human experience to generate the aims and methods by which further experience will flow in ordered richness." When equality is assumed in the collective process of discovering a common good, rigid attachments to narrow self-interest or exclusive visions of the good life loosen and possibilities for arriving at novel values and practices emerge. Democracy, then, involves what fellow pragmatist Mary Parker Follett (1930, 56) called "integrative behavior," or reflexively discovering those common values and ways of being that dissolve prior antagonisms. Not to be mistaken for compromise, integration involves the creative production of novelty, one which shores up a social connective tissue that simultaneously allows for the expression of oneself and society. Finding this novel ground requires habits of contest, dialogue, participation, and even collective inquiry (Abraham and Abramson 2017) that can identify inequities and transactionally articulate a revised political order. Integration encourages individuals and the community to be transformed through the process of democratic engagement. To be sure, the arrival of the common good is neither the prerequisite to democratic action nor its final end (cf. Schumpeter [1943] 2010, 226-8) but contingently produced and continually revised (Dewey [1939] 2021, 64-5).

"Stakeholder democracy," however, signals a concerning rethinking of democratic engagement and participation, distinct from the commitments that guide democratic theory's commitments to participation and action (Barber 1984; Fung and Wright 2003; Pateman 1970; Wolin 2018). Grounded in the logic of systems thinking, institutional engagement with and participation from stakeholders are cultivated not to arrive at the articulation of common values but to manage complexity. Rather than members of the public coming together to collectively confront different political visions and transactionally arriving at novel positions, circumscribed engagement among affected parties is staged for long-term institutional survival. Participation, as such, is not severed from political institutions but, under conditions of complexity, tied to only those interests that are affected by a problem and channeled for the perpetuation of political order. For instance, Coates, a member of a Public Participation Committee established by Daddario in 1977, developed a framework for stakeholder identification in policy assessments (OTA 1977, 3). According to the meeting minutes, Coates maintained that the relevant public here should not be confused "with the laity" but only those who have a stake in policy (2). Other committee members agreed, developing stakeholder identification techniques that if done in a systematic manner would not only ensure that "many groups would not be overlooked" but "would also provide a basis for limiting the number of stakeholders if, for some purposes, that [would be] necessary" (7). The priority, then, is not an empowered demos but managed participation.

Therefore, like Son's parsing of postwar democratic theory, practices oriented around stakeholder inclusion and participation depend on a kind of instrumentalism. However, this instrumental attitude is not limited to the realization of individual interest or results in a "contest of sovereign wills" (Son 2020,177). Instead, with stakeholder subjectivity, individuals may arrive at circumscribed forms of collective identification and collaboration with their stakeholder group. That is, forms of collective engagement emerge that may not be predicated on individual self-interest and distributional gains, but they are, indeed, limited to the stakeholder group rather than the public. For instance, stakeholder engagement may permit mobilization of a community group around environmental impact of a business or, as in the case of school infrastructure discussed above, distinct racial and political groups. But it limits wider forms of engagement-both among stakeholder groups involved in the policy process and among those parties not affected by a particular policy decision and, therefore, excluded. Individual interest becomes married to that of a specific group at the expense of negotiating across lines of difference and transactionally producing novel forms of commonality. This, I argue, is a more dynamic form of interest group pluralism, where one's connection to a group does not remain static (e.g., identity with "labor") but shifts based on affectedness in relation to a problem. Such a modulated instrumentalism does not reduce democracy to individualism or distributional issues alone (cf. Son 2020, 65), as it accommodates a politics of recognition (Fraser 1995; 2000), but neither does it encourage engagement with problems outside of one's 
own affected circumstances or establish novel ways of seeing oneself and others.

Second, because "stakeholder democracy" draws together affected parties, it erases distinctions between individuals and groups, providing political parity to qualitatively different actors. Reconfiguring democracy around the subject of stakeholders permits legitimate political participation for all affected parties, leveling the voice of individual citizens with large multinational corporations. This poses problems for collective decision making predicated on equality because it allows for structural inequalities to embed themselves within institutions. If stakeholder inclusion requires active participation among affected partiesthat is, to make one's voice heard, one must participate in the policy process - capitalism necessarily constrains equal participation among affected groups. For instance, if one were to participate as a stakeholder in the internet governance policy space, where multistakeholder inclusion is firmly institutionalized and celebrated (Carr 2015), an affected individual would have to find time to do so outside of every day working hours while telecommunication companies send paid representatives, undermining political equality (Marlin-Bennett 2001).

While corporate influence in democratic governance is a symptom of broader unexamined factors, genealogical attention to the discourses and material circuits that articulated the stakeholder in public institutions demonstrates the accidental circumstances by which corporate actors have come to hold a legitimate role in solving public problems. Predicating solutions to complexity on the inclusion of stakeholders initially emerged as a strategy for corporations to survive in dynamic environments, but the institutional circuitry between private research firms and public agencies, established in the context of postwar social welfare programs, permitted the movement of these ideas and practices into US public administration. The political rationality of systems thinking, then, is necessary to grasp how corporate voices became understood as legitimately required to solve complex problems (e.g., around climate change, social media, polarization, etc.). As such, governing through stakeholders not only provides space for corporate interests to determine policy that directly affects their business, but it goes further to name their participation in politics as democratically legitimate.

Finally, a turn to stakeholders as the subject of democratic practice amplifies rather than resolves the problem of expertise. If for Wolin (2008), the problem of midcentury democracy is an elitism that disables participation, and if for Son (2020), the problem is how diminished opportunities for participation are recast as sites for registering individual preferences and interests, the problem of "stakeholder democracy" is different. Here, opportunities to participate proliferate, but participatory mechanisms involve bringing different forms of "expert" knowledge to bear on a political issue. In being directly affected, whether as an individual or corporation, a network of activists or scientific body, stakeholders bring their own experience and knowledge to the table to manage complex social and political problems. Thus, the practice of stakeholder inclusion reinscribes elitism through participation by predicating the latter on the expertise an affected party holds rather than on the equal capacities of anyone. Rather than a faith in the equality of all, rather than cultivating political intelligence that can allow the public to make informed decisions on issues outside of their individual expertise and concern (Dewey [1939] 2021, 63), stakeholder democracy limits participation to those with a kind of expertise formed by shared affectedness. This necessarily reinforces a functionalist division of stakeholder groups and limits the capacity for stakeholders and nonaffected parties to transactionally discuss the values and principles that underwrite decisions on the common good. Dissolving the problem of expertise in a democracy requires habits of political intelligence that allow for individuals to understand and negotiate that which they do not know and that in which they have no clear interests (Son 2020, 22-3).

\section{THE PUZZLE OF CONTEMPORARY DEMOCRACY: BEYOND A CRITIQUE OF (NEO)LIBERALISM?}

Across multiple institutions, we are increasingly called upon as stakeholders to make our voices heard, to participate in political life, and yet there is little investigation into the category of the stakeholder, where it comes from, and its effects on democracy. My wager in this paper is that in historically mapping the political reasoning that articulates the stakeholder, in understanding the managerial logic that underpins it, I can clarify how midcentury transformations have produced a novel political subjectivity that orients democratic practice and sets limits to participatory politics. While I do not maintain that the making of stakeholders in the 1960s and 1970s can be linearly drawn to the present, that the political rationality of systems thinking is the discursive register from which transformations in democratic governance have proceeded, this genealogy recovers how managerialism, systems thinking, and problems of complexity constitute part of the story of democratic erosion.

Attending to the stakeholder brings to fore new ways of understanding the crisis of democracy that contributes to prominent debates on the relationship between (neo) liberalism and democracy. There is a deep literature that focuses on the problematic effects of neoliberalism on democracy (Brown 2015; 2019; Cahill and Konings 2017; Cooper 2017; Crouch 2004; Ong 2006; Peck 2010; Slobodian 2018; Streeck 2014; Vormann and Lammert 2019), which typically figures neoliberal policies and discourses as undermining political equality or otherwise dampening democratic engagement. Others, however, argue that democratic erosion is not symptomatic of neoliberalism, per se, but emerges from the contradictions of liberal democracy. Whether from feminist (Jaggar 1983; Pateman 1985; 1988), Black radical (Mills 2008), agonistic (Honig 1993; Laclau and Mouffe 
2001), postcolonial (Mehta 1990), polemical (Chambers 2013), or Tocquevillian (Deneen 2018) positions, this literature considers how liberalism tempers, dismisses, or remains logically incompatible with democracy. As Antonio Y. Vázquez-Arroyo $(2008 ; 2017)$ cautions, the rise of neoliberalism in the last part of the twentieth century does not mark a distinct break from the historical formation of liberal democracy; rather, it flourishes through the liberal institutions that depoliticize society and, consequently, undermine democratic action and participation. Annie McClanahan (2017) echoes this position, casting doubt on the novelty of neoliberal effects, such as the economization of nonmarket spheres of life, by locating practices and policies that economized higher education following the end of WWII.

Limited space precludes proper engagement with the diversity of positions that exist in this literature, but two assumptions tend to inform these critiques: an attention to "world-altering formations" (Brown 2019, 17) - that is, liberalism and neoliberalism - and a sense that what will energize democratic attachment is political participation. My argument does not displace these rich accounts, but it maintains that a singular focus on the depoliticizing effects of (neo) liberalism misses part of the story. Without understanding how the political rationality of systems thinking has produced democratic subjectivity, without assessing how stakeholder participation limits wider engagement, we fail to grasp how democratic detachment persists despite opportunities for political participation. Prior to the rise of neoliberalism in the 1980s and running alongside the liberal pluralism of the postwar era, political subjectivity was shaped by the managerial logic of systems thinking wherein circumscribed participation figured as managerial techniques to deal with problems of complexity. Rather than allowing for deep pluralization and democratic revision of collective attachments, rather than resolving the problem of expertise by cultivating habits of political intelligence that allow for collective decision making, stakeholder democracy limits substantive participation. That systems thinking, problems of complexity, and neoliberal discourses meet today is all the more reason to understand the contingent connection and "interplay" of distinct rationalities (Foucault 2008, 313). Therefore, my contribution to these debates is neither to logically question nor empirically doubt the critiques of (neo) liberalism but to offer a genealogical account of that which has been elided: how we became stakeholders.

\section{ACKNOWLEDGMENTS}

Deep gratitude is owed to the three referees and the editorial team, whose feedback significantly strengthened the framing of the argument and its contribution to the literature. Their patient engagement is felt throughout the manuscript. Earlier versions of the paper were improved by comments and support from Renée Marlin-Bennett, Bentley Allan, Louis
Galambos, Tarek Tutunji, Yehonatan Abramson, and Elizabeth Mendenhall. All remaining errors are mine.

\section{CONFLICT OF INTEREST}

The author declares no ethical issues or conflicts of interest in this research.

\section{ETHICAL STANDARDS}

The author affirms this research did not involve human subjects.

\section{REFERENCES}

Abraham, Kavi Joseph, and Yehonatan Abramson. 2017. “A Pragmatist Vocation for International Relations: The (Global) Public and Its Problems." European Journal of International Relations 23 (1): 26-48.

Ackoff, Russell. 1970. "A Concept of Corporate Planning." Long Range Planning 3 (1): 2-8.

Ackoff, Russell. 1974a. Redesigning the Future: A Systems Approach to Societal Problems. New York: John Wiley.

Ackoff, Russell. 1974b. "The Systems Revolution." Long Range Planning 7 (6): 2-20.

Amadae, S. M. 2003. Rationalizing Capitalist Democracy: The Cold War Origins of Rational Choice Liberalism. Chicago: University of Chicago Press.

Arnstein, Sherry R. 1977. "Technology Assessments: Opportunities and Obstacles." IEEE Transactions on Systems, Man, and Cybernetics SMC-7 (8): 571-82.

Bäckstrand, Karin. 2006. "Democratizing Global Environmental Governance? Stakeholder Democracy after the World Summit on Sustainable Development." European Journal of International Relations 12 (4): 467-98.

Barber, Benjamin R. 1984. Strong Democracy: Participatory Politics for a New Age. Oakland: University of California Press.

Barry, Andrew, Thomas Osborne, and Nikolas Rose, eds. 1996. Foucault and Political Reason: Liberalism, Neo-Liberalism, and Rationalities of Government. Chicago: University of Chicago Press.

Bertalanffy, Ludwig von. 1968. General System Theory: Foundations, Development, Applications. New York: George Braziller.

Bevir, Mark. 2006. "Democratic Governance: Systems and Radical Perspectives." Public Administration Review 66 (3): 426-36.

Bevir, Mark. 2010. Democratic Governance. Princeton, NJ: Princeton University Press.

Boltanski, Luc, and Ève Chiapello. 2007. The New Spirit of Capitalism, trans. Gregory Elliott. London: Verso.

Brenner, Neil, and Nik Theodore. 2002. "Cities and the Geographies of 'Actually Existing Neoliberalism."” Antipode 34 (3): 349-79.

Brown, Wendy. 2015. Undoing the Demos: Neoliberalism's Stealth Revolution. New York: Zone.

Brown, Wendy. 2019. In the Ruins of Neoliberalism: The Rise of Antidemocratic Politics in the West. New York: Columbia University Press.

Burchell, Graham. 1993. "Liberal Government and Techniques of the Self." Economy and Society 22 (3): 267-82.

Cahill, Damien, and Martijn Konings. 2017. Neoliberalism. Cambridge: Polity Press.

Caldwell, Bruce. 2016. "F. A. Hayek and the Economic Calculus." History of Political Economy 48 (1): 151-80.

Carr, Madeline. 2015. "Power Plays in Global Internet Governance." Millennium - Journal of International Studies 43 (2): 640-59.

Chambers, Samuel A. 2013. The Lessons of Rancière. Oxford: Oxford University Press.

Chandler, Alfred D. 1977. The Visible Hand: The Managerial Revolution in American Business. Cambridge, MA: Harvard University Press. 
Chandler, David. 2014. "Beyond Neoliberalism: Resilience, the New Art of Governing Complexity." Resilience 2 (1): 47-63.

Churchman, Charles West. 1968. The Systems Approach. New York: Delacorte Press.

Clowse, Barbara Barksdale. 1981. Brainpower for the Cold War: The Sputnik Crisis and National Defense Education Act of 1958.

Westport, CT: Greenwood Press.

Coates, Joseph F. 1971. "Technology Assessment: The Benefits, the Costs, the Consequences." Futurist 5 (6): 225-31.

Coates, Joseph F. 1976. "The Role of Formal Models in Technology Assessment." Technological Forecasting and Social Change 9 (1): 139-90.

Congressional Research Service. N.d. Public Participation and Technology Assessment: A Survey of the Legislative History of the Office of Technology Assessment. Library of Congress. http:// ota.fas.org/reports/0086.pdf. (January 11, 2017).

Connolly, William E. 2013. The Fragility of Things: Self-Organizing Processes, Neoliberal Fantasies, and Democratic Activism. Durham, NC: Duke University Press.

Cooper, Melinda. 2011. "Complexity Theory after the Financial Crisis: The Death of Neoliberalism or the Triumph of Hayek?" Journal of Cultural Economy 4 (4): 371-85.

Cooper, Melinda. 2017. Family Values: between Neoliberalism and the New Social Conservatism. Princeton, NJ: Princeton University Press.

Crouch, Colin. 2004. Post-Democracy. Cambridge: Polity.

Dean, Mitchell. 1999. Governmentality: Power and Rule in Modern Society. London: SAGE.

Deneen, Patrick J. 2018. Why Liberalism Failed. New Haven, CT: Yale University Press.

Dewey, John. [1939] 2021. "Creative Democracy-The Task before Us.” In America's Public Philosopher: Essays on Social Justice, Economics, Education, and the Future of Democracy, ed. Eric Thomas Weber, 59-65. New York: Columbia University Press.

Eagleton-Pierce, Matthew. 2016. Neoliberalism: The Key Concepts. London: Routledge.

Eichelberger, R. Tony. 1978. "Multiple Stakeholders and Evaluation." Paper presented at the Annual Meeting of the American Educational Research Association. Toronto, Canada. https://files.eric.ed.gov/fulltext/ED164565.pdf.

Emery, F. E., and E. L. Trist. 1965. "The Causal Texture of Organizational Environments." Human Relations 18 (1): 21-32.

Ercan, Selen A., and Jean-Paul Gagnon. 2014. "The Crisis of Democracy: Which Crisis? Which Democracy?" Democratic Theory 1 (2): 1-10.

Esty, Benjamin, and Allison Ciechanover. 2021. "Airbnb during the Pandemic: Stakeholder Capitalism Faces a Critical Test." HBS Case No. 221-050. Working Paper. https://papers.ssrn.com/ abstract $=3850750$.

Ferguson, James. 2010. "The Uses of Neoliberalism.” Antipode 41 (S1): 166-84.

Foa, R. S., A. Klassen, M. Slade, A. Rand, and R. Collins. 2020. "The Global Satisfaction with Democracy Report 2020.” Cambridge: Centre for the Future of Democracy. https://

www.bennettinstitute.cam.ac.uk/media/uploads/files/ DemocracyReport2020.pdf.

Follett, Mary Parker. 1930. Creative Experience. New York: Longman, Green and Co.

Foucault, Michel. 1977. Discipline and Punish: The Birth of the Prison. New York: Pantheon.

Foucault, Michel. 1984. The Foucault Reader, ed. Paul Rabinow. New York: Pantheon.

Foucault, Michel. 2008. The Birth of Biopolitics: Lectures at the Collège de France, 1978-1979, ed. Michael Snellart, trans. Graham Burchell. New York: Palgrave.

Fraser, Nancy. 1995. "From Redistribution to Recognition? Dilemmas of Justice in a 'Post-Socialist' Age." New Left Review 212: 68-93. https://newleftreview.org/issues/i212/articles/nancyfraser-from-redistribution-to-recognition-dilemmas-of-justice-ina-post-socialist-age.

Fraser, Nancy. 2000. "Rethinking Recognition.” New Left Review 3: 107-20. https://newleftreview.org/issues/ii3/articles/nancy-fraserrethinking-recognition.

Freeman, R. Edward. 1984. Strategic Management: A Stakeholder Approach. Boston: Pitman.
Freeman, R. Edward, Jeffrey S. Harrison, Andrew C. Wicks, Bidhan L. Parmar, and Simone de Colle. 2010. Stakeholder Theory: The State of the Art. Cambridge: Cambridge University Press.

Fung, Archon, and Erik Olin Wright. 2003. Deepening Democracy: Institutional Innovations in Empowered Participatory Governance. London: Verso.

Garman, Keats, and Carolyn Hunter. 1978. "Community Surveys: Grassroots Approaches. Keys to Community Involvement Series: 13." National School Public Relations Association; Northwest Regional Educational Lab ED 161 129. https://files.eric.ed.gov/ fulltext/ED161129.pdf.

Green, Harold P. 1968. "Safety Determinations in Nuclear Power Licensing: A Critical View." Notre Dame Law Review 43 (5): 633-56.

Hahn, Walter A. 1975. "Technology Assessment and the Congress." Public Administration Review 35 (1): 76-7.

Hahn, Walter A., and Rosemary A. Chalk. 1972. The Technology Assessment Act of 1972. Q 125 U.S. D1. Congressional Research Service. https://ota.fas.org/reports/CRS-12-1972.pdf.

Hayek, F. A. [1964] 1994. "The Theory of Complex Phenomena." In Readings in the Philosophy of Social Science, eds. Michael Martin and Lee C. McIntyre, 55-70. Cambridge, MA: MIT Press.

Heyck, Hunter. 2015. Age of System: Understanding the Development of Modern Social Science. Baltimore, MD: Johns Hopkins University Press.

Honig, Bonnie. 1993. Political Theory and the Displacement of Politics. Ithaca, NY: Cornell University Press.

Hood, Paul D., and Laird Blackwell. 1975. An Assessment System for Competence Based Education: The Educational Development, Dissemination, and Evaluation Training Program. Washington, DC: National Institute of Education (DHEW). https:// files.eric.ed.gov/fulltext/ED126142.pdf.

Jaggar, Alison M. 1983. Feminist Politics and Human Nature. Oxford: Rowman \& Littlefield Publishers.

Joseph, Jonathan. 2013. "Resilience as Embedded Neoliberalism: A Governmentality Approach.” Resilience 1 (1): 38-52.

Klein, Naomi. 2014. The Shock Doctrine: The Rise of Disaster Capitalism. London: Penguin UK.

Koenig, Adolph J. 1970. Educational Research and Development: Implications for Research Management from a National Perspective. Washington, DC: American Educational Research Association.

Laclau, Ernesto, and Chantal Mouffe. 2001. Hegemony and Socialist Strategy: Towards a Radical Democratic Politics. London: Verso.

Legacy, Crystal. 2010. "Investigating the Knowledge Interface between Stakeholder Engagement and Plan-Making." Environment and Planning A 42 (11): 2705-20.

acdonald, Terry. 2008. Global Stakeholder Democracy: Power and Representation beyond Liberal States. Oxford: Oxford University Press.

March, James G., and Herbert A. Simon. 1958. Organizations. New York: Wiley.

Markley, O. W. 1975a. The Normative Structure of Knowledge Production and Utilization in Education,Vol. 1. Case Studies of the Infrastructure of Educational $R$ and D. Washington, DC: National Institute of Education (DHEW). http://files.eric.ed.gov/fulltext/ ED033435.pdf.

Markley, O. W. 1975b. The Normative Structure of Knowledge Production and Utilization in Education,Vol. 2. Case Studies of the Infrastructure of Educational $R$ and $D$. Washington, DC: National Institute of Education (DHEW). http://files.eric.ed.gov/fulltext/ ED033435.pdf.

Marlin-Bennett, Renée. 2001. "ICANN and Democracy: Contradictions and Possibilities." Info 3 (4): 299-311.

Mayo, Louis H. 1969. Scientific Method, Adversarial System, and Technology Assessment." Program of Policy Studies in Science and Technology. Washington, DC: George Washington University.

McCaffrie, Brendan, and Sadiya Akram. 2014. "Crisis of Democracy? Recognizing the Democratic Potential of Alternative Forms of Political Participation.” Democratic Theory $1(2): 47-55$.

McClanahan, Annie J. 2017. "Becoming Non-Economic: Human Capital Theory and Wendy Brown's Undoing the Demos." Theory \& Event 20 (2): 510-19. 
McClure, Larry. 1977. The Regional Laboratory Connection. Improving Educational Practices through Systematic Research and Development. Portland, OR: Northwest Regional Educational Lab.

McConnell, J. Douglas. 1971. "Strategic Planning: One Workable Approach." Long Range Planning 4 (2): 2-6.

Mehta, Uday. 1990. "Liberal Strategies of Exclusion." Politics \& Society 18 (4): 427-54.

Merkel, Wolfgang. 2014. "Is There a Crisis of Democracy?" Democratic Theory 1 (2): 11-25.

Merkel, Wolfgang, and Jean-Paul Gagnon. 2016. "Democracies and Their Crises Reconsidered." Democratic Theory 3 (1): 91-109.

Miller, Peter, and Nikolas Rose. 1990. "Governing Economic Life." Economy and Society 19 (1): 1-31.

Mills, Charles W. 2008. "Racial Liberalism.” PMLA 123 (5): 1380-97.

Mueller, Milton. 2002. Ruling the Root: Internet Governance and the Taming of Cyberspace. Cambridge, MA: MIT Press.

Ong, Aihwa. 2006. Neoliberalism as Exception: Mutations in Citizenship and Sovereignty. Durham, NC: Duke University Press.

Office of Technology Assessment (OTA). 1975. "Annual Report to the Congress." https://ota.fas.org/reports/7500.pdf.

Office of Technology Assessment (OTA). 1977. "Memorandum: From Emilio Q. Daddario to Public Participation Committee." https://ota.fas.org/reports/0351.pdf.

Pateman, Carole. 1970. Participation and Democratic Theory. Cambridge: Cambridge University Press.

Pateman, Carole. 1985. The Problem of Political Obligation: A Critique of Liberal Theory. Oakland: University of California Press.

Pateman, Carole. 1988. The Sexual Contract. Redwood City, CA: Stanford University Press.

Peck, Jamie. 2010. Constructions of Neoliberal Reason. Oxford: Oxford University Press.

Rancière, Jacques. 2014. Hatred of Democracy, trans. Steve Corcoran. London: Verso Books.

Rose, Nikolas. 1993. "Government, Authority and Expertise in Advanced Liberalism." Economy and Society 22 (3): 283-99.

Rosenbluth, Frances, and Ian Shapiro. 2018. Responsible Parties: Saving Democracy from Itself. New Haven, CT: Yale University Press.

Rossi, Peter H., Mark W. Lipsey, and Howard E. Freeman. 2003. Evaluation: A Systematic Approach. Thousand Oaks, CA: SAGE Publications.

Schumpeter, Joseph A. [1943] 2010. Capitalism, Socialism and Democracy. New York: Routledge.

Slobodian, Quinn. 2018. Globalists: The End of Empire and the Birth of Neoliberalism. Cambridge, MA: Harvard University Press.

Smith, William E. 2008. The Creative Power: Transforming Ourselves, Our Organizations, and Our World. New York: Routledge.
Son, Kyong-Min. 2020. The Eclipse of the Demos: The Cold War and the Crisis of Democracy before Neoliberalism. Lawrence: University Press of Kansas.

Streeck, Wolfgang. 2014. "How Will Capitalism End?" New Left Review (87): 35-64. https://newleftreview.org/issues/ii87/articles/ wolfgang-streeck-how-will-capitalism-end.

Taylor, Frederick Winslow. 2012. The Principles of Scientific Management. Auckland, New Zealand: The Floating Press.

Thomas, Thomas C. 1967. Educational Policy for the Inner City. Washington, DC: Office of Education (DHEW).

Thomas, Thomas C. 1969. On Improving Urban School Facilities and Education. Menlo Park: Stanford Research Institute.

Thomas, Thomas C., and Willis W. Harman. 1972. Critical Issues in the Future of American Education." Menlo Park: Stanford Research Institute.

Urban, Wayne J. 2010. More Than Science and Sputnik: The National Defense Education Act of 1958. Tuscaloosa: University of Alabama Press.

Urbinati, Nadia. 2019. Me the People: How Populism Transforms Democracy. Cambridge, MA: Harvard University Press.

US House of Representatives. 1967. "Technology Assessment Seminar: Proceedings before the Subcommittee on Science, Research, and Development of the Committee on Science and Astronautics." US House of Representatives Ninetieth Congress, First Session.

Vázquez-Arroyo, Antonio Y. 2008. "Liberal Democracy and Neoliberalism: A Critical Juxtaposition." New Political Science 30 (2): 127-59.

Vázquez-Arroyo, Antonio Y. 2017. "Refurbishing Liberal Democracy? On Wendy Brown's Undoing the Demos." Theory \& Event 20 (2): 528-36.

Venugopal, Rajesh. 2015. "Neoliberalism as Concept." Economy and Society 44 (2): 165-87.

Vormann, Boris, and Christian Lammert. 2019. Democracy in Crisis: The Neoliberal Roots of Popular Unrest, trans. Susan H. Gillespie. Philadelphia: University of Pennsylvania Press.

Walker, Jeremy, and Melinda Cooper. 2011. "Genealogies of Resilience: From Systems Ecology to the Political Economy of Crisis Adaptation." Security Dialogue 42 (2): 143-60.

Westbrook, Robert. 2021. "Creative Democracy - the Task Still before Us." Hastings Center Report 51 (S1): S29-35.

Wolin, Sheldon S. 2008. Democracy Incorporated: Managed Democracy and the Specter of Inverted Totalitarianism. Princeton, NJ: Princeton University Press.

Wolin, Sheldon S. 2018. Fugitive Democracy: And Other Essays. Princeton, NJ: Princeton University Press.

Zebrowski, Chris. 2013. "The Nature of Resilience." Resilience 1 (3): $159-73$. 